\title{
ANALISIS FAKTOR-FAKTOR YANG MEMPENGARUHI IMPLEMENTASI PENGANGGARAN BERBASIS KINERJA DI KOTA BANDA ACEH
}

\author{
Roza Maulina*1, Syukri Abdullah ${ }^{* 2}$ \\ ${ }^{1,2}$ Program Studi Akuntansi Fakultas Ekonomi dan Bisnis Universitas Syiah Kuala \\ e-mail: rozamaulina@yahoo.co.id ${ }^{* 1}$, syukriyabdullah@unsyiah.ac.id ${ }^{* 2}$
}

\begin{abstract}
This research aims to empirically examine the influence of leadership, human resources, monitoring and evaluation, and regulation regarding the implementation of performance-based budgeting in the Banda Aceh city. Sampling was done with the purposive sampling analysis method the used is multiple linear regression using SPSS 22. This analysis data show there are significantly effect on leadership, human resoutces, monitoring and evaluation, and regulation to implementation of performance based-bugeting in the Banda Aceh city. In partial leadership, human resoutces, monitoring and evaluasi, and regulation do not significantly affect the implementation performance based-budget.
\end{abstract}

Keywords: Performance-Based Budgeting, Leadership, Human Resources, Monitoring and Evaluation, Regulation

\section{Pendahuluan}

Pelaksanaan reformasi pengelolaan keuangan, menimbulkan tuntutan yang beragam terhadap pengelolaan daerah yang baik. Seluruh pihak/masyarakat menginginkan terciptanya sistem pengelolaan keuangan yang dapat dilaksanakan secara profesional, transparan dan bertanggung jawab dengan memanfaatkan sumber daya yang ada secara efisien dan efektif. Kemudian reformasi anggaran ditandai dengan peraturan Undang-Undang Nomor 17 Tahun 2003 tentang Keuangan Negara serta Undang-undang Nomor 32 tentang Pemerintahan Daerah dan Nomor 33 Tahun 2004 tentang Perimbangan Keuangan antara Pemerintah Pusat dan Pemerintah Daerah. Reformasi ini dimaksudkan untuk memperkenalkan sistem penganggaran berbasis kinerja (Performance Based Budgeting) sebagai pengganti sistem penganggaran lama dengan sistem tradisional yang bersifat incrementalism.

Anggaran berbasis kinerja merupakan sistem penyusunan anggaran yang berorientasi pada pencapaian kinerja yang lebih fokus pada output dan outcome serta pelaksanaanya dapat dipertanggungjawabkan sehingga dapat tercapai tingkat efisiensi dan efektifnya suatu program. Sistem penganggaran pemerintah daerah diharapkan memiliki dampak pada peningkatan kinerja dan meningkatkan penggunaan instansi pemerintah (Nur, Nunuy dan Oman, 2014).
Pendekatan anggaran berbasis kinerja disusun untuk mengatasi berbagai kelemahan yang terdapat dalam anggaran tradisional, khususnya kelemahan yang disebabkan tidak adanya tolak ukur yang digunakan untuk mengukur kinerja dalam pencapaian tujuan dan sasaran pelayanan publik. Pendekatan ini menggeser penekanan penganggaran dari sebelumnya yang sangat menekankan pos belanja pada kinerja terukur dari aktivitas dan program kerja. Fokus utama dari pendekatan ini adalah pada tingkat efisiensi penyelenggaraan aktivitas. Anggaran dengan pendekatan kinerja sangat menekankan pada konsep value for money (ekonomi, efisiensi dan efektivitas) dan pengawasan atas kinerja output. Pendekatan ini juga mengutamakan mekanisme penentuan dan pembuatan prioritas tujuan serta pendekatan yang sistematik dan rasional dalam proses pengambilan keputusan (Mardiasmo, 2002: 84).

Kota Banda Aceh merupakan salah satu kota di provinsi Aceh yang telah menerapkan sistem penganggaran berbasis kinerja pada penyelenggaraan pemerintahnya dan dalam laporan keuanganya. Menurut opini Badan Pemeriksaan Keuangan (BPK), laporan keuangan Pemerintah Kota Banda Aceh menyajikan secara wajar, dalam semua hal yang material, posisi keuangan Pemerintah Kota Banda Aceh tanggal 31 Desember 2013 dan realisasi anggaran, serta arus kas untuk tahun yang berakhir pada tanggal-tanggal tersebut sesuai dengan Standar 
Akuntansi Pemerintahan (SAP). Dengan ini BPK memberikan opini Wajar Tanpa Pengecualian (WTP) yang ke-6 secara berturut-turut untuk Laporan Keuangan Pemerintah Kota Banda Aceh Tahun Anggaran 2013.

Secara formalitas pemerintah kota Banda Aceh sudah mengaplikasinya, tetapi tidak menjadi jaminan terhadap pencapaian kinerjanya. Dalam pelaksanaannnya masih terdapat kesalahan dan penyimpangan dalam eksekusi ditataran teknis sehingga pelaksanaannya belum memberikan kontribusi yang optimal. Belum optimalnya pengelolaan keuangan tercermin pada Laporan Realisasi Anggaran 3 tahun terakhir (2011-2013). Hal ini dapat terlihat pada Tabel 1.1 Ringkasan Pos Belanja LRA Pemerintah Kota Banda Aceh.

Tabel 1.1

Ringkasan Pos Belanja LRA Pemerintah Kota Banda Aceh

\begin{tabular}{|c|c|c|c|}
\hline Tahun Anggaran & APBD & Realisasi & Selisih \\
\hline 2011 & 750.476 .593 .750 & 704.068 .180 .164 & 46.408 .413 .586 \\
\hline 2012 & 812.298 .188 .664 & 752.919 .172 .455 & 59.379 .016 .209 \\
\hline 2013 & 985.975 .685 .419 & 905.808 .725 .719 & 80.166 .959 .701 \\
\hline
\end{tabular}

Sumber: LRA Pemerintah kotaBanda Aceh (2011-2013).

Berdasarkan data diatas terlihat bahwa penyerapan angggaran masih menjadi permasalahan dalam bidang pengelolaan keuangan, terlihat dari jumlah yang dianggarkan dengan realisasinya masih belum mencapai target setiap tahunnya. Selanjutknya hasil pemeriksaan BPK atas laporan keuangan pemerintah kota Banda Aceh Tahun Anggaran 2013 mengungkapkan ada 5 temuan kelemahan Sistem Pengendalian Intern (SPI) dan 5 temuan ketidakpatuhan terhadap peraturan perundangundangan. Kondisi ini tidak sesuai yang diharapkan (direncanakan) dengan prinsip-prinsip pengelolaan keuangan yaitu ekonomis, efesiensi, efektif (value for money).

Buku Pedoman Penyusunan Anggaran Berbasis Kinerja yang diterbitkan Badan Pengawasan Keuangan dan Pembangunan (BPKP) tahun 2005 menyatakan: tuntutan pentingnya pelaksanaan penyusunan anggaran berbasis kinerja, ternyata membawa konsekuensi yang harus disiapkan beberapa faktor keberhasilan implementasi penggunaan anggaran berbasis kinerja, yaitu:

1. Kepemimpinan dan komitmen dari seluruh komponen organisasi

2. Fokus penyempurnaan administrasi secara terus menerus

3. Sumber daya yang cukup untuk usaha penyempurnaan tersebut (uang, waktu dan orang)
4. Penghargaan (reward) dan sanksi (punishment) yang jelas

5. Keinginan yang kuat untuk berhasil

Menurut Izzaty (2011) dalam penelitianya menunjukkan bahwa variabel gaya kepemimpinan dan kualitas sumber daya manusia terbukti mempengaruhi penerapan anggaran berbasis kinerja badan layanan umum (BLU). Sementara menurut Indrayati (2008) dalam Mesfriati (2009), kendala-kendala yang dihadapi dalam penerapan anggaran berbasis kinerja antara lain resistensi aparat pelaksana maupun anggota legislatif, keterbatasan sumber daya manusia, kurangnya standard dan acuan tentang penyusunan APBD berdasarkan performance budgeting.

Penelitian ini mengacu pada penelitian yang dilakukan oleh Sabri (2013) dengan judul faktor-faktor yang mempengaruhi implementasi pengelolaan anggaran berbasis kinerja di Kota Bukittinggi. Hasil penelitian ini membuktikan bahwa kepemimpinan, sumber daya pengelola anggaran serta monitoring dan evaluasi berpengaruh signifikan positif terhadap implementasi pengelolaan anggaran berbasis kinerja di Kota Bukittinggi. Perbedaan penelitian ini dengan penelitian sebelumnya terletak pada daerah penelitian, periode waktu penelitian, dan penambahan satu variabel baru yaitu regulasi.

Berdasarkan uraian latar belakang yang dikemukakan, maka peneliti tertarik untuk melakukan penelitian mengenai "Analisis Faktor-Faktor yang 


\section{Mempengaruhi Implementasi Penganggaran Berbasis Kinerja di Kota Banda Aceh".}

Penelitian ini bertujuan: (1) Untuk menguji dan menganalisis pengaruh gaya kepemimpinan terhadap implementasi penganggaran berbasis kinerja di Kota Banda Aceh. (2) Untuk menguji dan menganalisis pengaruh sumber daya manusia terhadap implementasi penganggaran berbasis kinerja di Kota Banda Aceh. (3) Untuk menguji dan menganalisis pengaruh monitoring dan evaluasi terhadap implementasi penganggaran berbasis kinerja di Kota Banda Aceh.

(4) Untuk menguji dan menganalisis pengaruh regulasi terhadap implementasi penganggaran berbasis kinerja di Kota Banda Aceh.

\section{Kerangka Teoritis Dan Pengembangan Hipotesis \\ Anggaran Berbasis Kinerja}

Menurut Sembiring (2009) anggaran berbasis kinerja merupakan sistem penganggaran yang memberikan fokus pada fungsi dan kegiatan pada suatu unit organisasi, dimana setiap kegiatan yang ada tersebut harus dapat diukur kinerjanya. Anggaran berbasis kinerja sebagai prosedur atau mekanisme yang dimaksudkan untuk memperkuat kaitan antara dana yang diberikan kepada entitas sektor publik dengan outcome dan/atau outcome mereka melalui penggunaan informasi kinerja formal dalam pengambilan keputusan alokasi sumber daya (Robinson and Brumby, 2005 dalam Suhardjanto dan Cahya, 2008).

Sedangkan Menurut Young (2013), anggaran berbasis kinerja memiliki empat karakteristik yang harus dipenuhi, yaitu: (1) menetapkan tujuan yang ingin dicapai, (2) memberikan informasi dan data tentang kinerja masa lalu sehingga dapat memandingkan yang diharapkan dan aktual, (3) penyesuaian program yang dibuat baik pada saat ini atau selama siklus penyusunan anggaran masa depan untuk menutup kesenjangan kinerja yang mungkin ada, (4) PBB memberikan kesempatan bagi evaluasi program reguler atau khusus

Selanjutnya menurut De Jong et al. (2013), mengemukakan tujuan anggaran berbasis kinerja adalah (1) Meningkatkan transparansi pengeluaran pemerintah dan hasil terkait untuk memberikan pemilih dan peluang legislatif yang lebih baik untuk akuntabilitas dan pengawasan. Hal ini melibatkan mengintegrasikan data kinerja ke dalam dokumen anggaran dan membutuhkan pengukuran dan pelaporan informasi kinerja, (2) Meningkatan alokasi dan pengelolaan sumber daya yang efektif. Hal ini tidak hanya membutuhkan pengukuran dan pelaporan informasi kinerja tetapi juga benar-benar menggunakan informasi ini untuk menginformasikan keputusan yang dibuat dalam proses anggaran.

\subsection{Sistem Pengelolaan Keuangan Daerah}

Menurut Sembiring (2009) anggaran berbasis kinerja merupakan sistem penganggaran yang memberikan fokus pada fungsi dan kegiatan pada suatu unit organisasi, dimana setiap kegiatan yang ada tersebut harus dapat diukur kinerjanya. Anggaran berbasis kinerja sebagai prosedur atau mekanisme yang dimaksudkan untuk memperkuat kaitan antara dana yang diberikan kepada entitas sektor publik dengan outcome dan/atau outcome mereka melalui penggunaan informasi kinerja formal dalam pengambilan keputusan alokasi sumber daya (Robinson and Brumby, 2005 dalam Suhardjanto dan Cahya, 2008).

Sedangkan Menurut Young (2013), anggaran berbasis kinerja memiliki empat karakteristik yang harus dipenuhi, yaitu: (1) menetapkan tujuan yang ingin dicapai, (2) memberikan informasi dan data tentang kinerja masa lalu sehingga dapat memandingkan yang diharapkan dan aktual, (3) penyesuaian program yang dibuat baik pada saat ini atau selama siklus penyusunan anggaran masa depan untuk menutup kesenjangan kinerja yang mungkin ada, (4) PBB memberikan kesempatan bagi evaluasi program reguler atau khusus

Selanjutnya menurut De Jong et al. (2013), mengemukakan tujuan anggaran berbasis kinerja adalah (1) Meningkatkan transparansi pengeluaran pemerintah dan hasil terkait untuk memberikan pemilih dan peluang legislatif yang lebih baik untuk akuntabilitas dan pengawasan. Hal ini melibatkan mengintegrasikan data kinerja ke dalam dokumen anggaran dan membutuhkan pengukuran dan pelaporan informasi kinerja, (2) Meningkatan alokasi dan pengelolaan sumber daya yang efektif. Hal ini tidak hanya membutuhkan pengukuran dan pelaporan informasi kinerja tetapi juga benar-benar menggunakan informasi ini untuk menginformasikan keputusan yang dibuat dalam proses anggaran. 


\section{Faktor-Faktor yang Mempengaruhi Implementasi Penganggaran Berbasis Kinerja}

Menurut Kerlinger dan Padhazur (2002) dalam Izzaty (2011), Faktor kepemimpinan mempunyai peran yang sangat penting dalam meningkatkan kinerja pegawai karena kepemimpinan yang efektif memberikan pengarahan terhadap usaha-usaha semua pekerja dalam mencapai tujuan-tujuan organisasi. Kepemimpinan memungkinkan fleksibilitas dalam proses penyusunan anggaran dan memberikan peluang kepada karyawan untuk terlibat dalam perancangan arah organisasi, mengekspresikan ide-ide mereka tentang bagaimana perusahaan sebaiknya beroperasi, dan memanfaatkan bakat mereka secara efektif (Izzaty: 2011).

Apabila orang-orang yang menjadi pengikut (bawahan) dapat dipengaruhi kekuatan kepemimpinan yang dimiliki oleh atasan, maka mereka (bawahan) akan mengikuti kehendak pimpinannya dengan sadar, rela, dan sepenuh hati. Menurut Dharma (2000) dalam Alfiandri (2010) membagi gaya kepemimpinan dalam empat bagian, yaitu:

1. Gaya instruktif, gaya ini bercirikan komunikasi satu arah, pemimpin memberikan batasan peranan pengikutnya dan memberi tahu mereka tentang apa, bagaimana, bilamana, dan dimana melaksanakan berbagai tugas. Inisiatif pemecahan masalah dan pembuatan keputusan semata-mata dilakukan oleh pemimpin. Pemecahan masalah dan keputusan diumumkan, dan pelaksanaannya diawasi secara ketat oleh pemimpin.

2. Gaya Konsultasi, bercirikan komunikasi dua arah, pemimpin masih banyak memberikan pengarahan dan masih membuat hampir sama dengan keputusan, tetapi hal ini diikuti dengan perilaku mendukung dan berusaha mendengar perasaaan pengikut tentag keputusan yang dibuat serta tentang ide-ide dan saran-saran mereka.

3. Gaya Partisipasi, menempatkan posisi kontrol atas pemecahan masalah dan pembuatan keputusan dipegang secara bergantian. Komunikasi dua arah ditingkatkan, dan peranan pemimpin adalah secara aktif mendengar. Tanggung jawab pemecahan masalah dan pembuatan keputusan sebagian besar berada pada pihak pengikut.

4. Gaya Delegasi, merupakan rendahnya pengarahan yang dilakukan oleh seorang pemimpin, karena pemimpin mendiskusikan masalah bersam-sama dengan bawahan sehingga tercatat kesepakatan mengenai definisi masalah yang kemudian proses pembuatan keputusan didelegasikan secara keseluruan kepada bawahan.

Menurut Izzaty (2011) sumber daya manusia merupakan salah satu faktor internal yang memegang peranan penting berhasil tidaknya suatu organisasi dalam mencapai tujuan sehingga perlu diarahkan melalui manajemen sumber daya manusia yang efektif dan efisien. Faktor sumber daya manusia (SDM) mempunyai peran penting dalam mencapai tujuan suatu daerah karena SDM yang melaksanakan segala komponen yang telah direncanakan. Sumber daya manusia menjadi pilar peyangga utama sekaligus penggerak roda organisasi dalam usaha mewujudkan visi dan misi serta tujuan dari organsasi tersebut (Wiley, 2002 dalam Azhar, 2007).

Sedangkan Mardiasmo (2002) mengatakan bahwa faktor yang mempengaruhi keberhasilan pengelolaan anggaran berbasis kinerja diantaranya, perencaanan sumber daya yang akan mengelola, pembinaan sumber daya tersebut, kepemimpinan dalam pengeolaan keuangan serta monitoring dan evaluasi pelaksanaan pengelolaan keuangan. Beberapa hal tersebut pada dasarnya tidak berbeda baik konsepsi maupun aplikasinya.

Monitoring dimaksudkan untuk menilai apakah sumber proyek (input) akan dilaksanakan dan digunakan dalam menghasilkan output yang dituju. Sementara itu evaluasi merupakan proses penilaian pencapaian tujuan dan pengungkapan masalah kinerja program/kegiatan untuk memberikan umpan balik bagi peningkatan kualitas kinerja program/kegiatan. (Muktiali, 2009)

Dan selanjutnya dalam menyusun keuangan daerah diperlukan peraturan atau ketetapan yang berlaku dan terkadang untuk menyempurnakan peraturan agar dapat berorientasi pada tujuan, maka perlu adanya perubahan dalam peraturan tersebut. Menurut Azhar (2007) regulasi adalah persepsi respoden tentang perubahan peraturan, keputusan dan perundangan dalam waktu yang singkat, dan perubahan tersebut sangat berbeda dengan peraturan sebelumnya. Regulasi ini merupakan hal yang penting dalam proses pertanggungjawaban karena regulasi diatur dalam mekanisme dan tata cara pertanggungjawaban serta hal-hal apa saja yang harus dilakukan oleh pimpinan serta hal-hal apa saja yang 
harus dilakukan oleh pimpinan organisasi beserta jajarannya dan hal-hal yang tidak boleh dilakukan oleh pimpinan organisasi beserta jajarannya sehingga ada pimpinan yang jelas antara yang salah dengan yang benar (Bastian, 2010:393).

\section{Hipotesis}

Berdasarkan perumusan masalah, maka hipotesis yang berkaitan dengan penelitian ini, yaitu:

1. Kepemimpinan, sumber daya manusia, monitoring dan evaluasi, dan regulasi secara simultan berpengaruh terhadap implementasi penganggaran berbasis kinerja di Kota Banda Aceh.

2. Kepemimpinan secara parsial berpengaruh terhadap implementasi penganggaran berbasis kinerja di Kota Banda Aceh.

3. Sumber daya manusia secara parsial berpengaruh terhadap implementasi penganggaran berbasis kinerja di Kota Banda Aceh.

4. Monitoring dan evaluasi secara parsial berpengaruh terhadap implementasi penganggaran berbasis kinerja di Kota Banda Aceh.

5. Regulasi secara parsial berpengaruh terhadap implementasi penganggaran berbasis kinerja di Kota Banda Aceh.

\section{Metode Penelitian}

\section{Desain Penelitian}

Penelitian ini menggunakan studi kausal, menurut Bougie dan Sekaran (2010:108) studi kausal yaitu tipe hubungan yang menjelaskan pengaruh variabel independen terhadap variabel dependen atau tipe hubungan yang menjelaskan hubungan sebabakibat. Peneliti menggunakan desain penelitian ini untuk memberikan bukti empiris dan menganalisis faktor kepemimpinan, sumber daya manusia, monitoring dan evaluasi, dan regulasi sebagai variabel independen terhadap implementasi penganggaran berbasis kinerja di Kota Banda Aceh sebagai variabel dependen. Selain itu, horizon waktu yang digunakan merupakan studi cross-sectional dimana pada penelitian ini data yang dikumpulkan hanya sekali dikumpulkan, mungkin selama periode harian, mingguan, atau bulanan dalam rangka menjawab pertanyaan penelitian.

\section{Populasi dan Sampel Penelitian}

Populasi penelitian ini adalah semua pejabat struktural pada Satuan Kerja Perangkat Daerah (SKPD). Teknik penetuan sampel penelitian adalah purposive sampling. Adapun kriteria pemilihan sampel dalam penelitian ini adalah sebagai berikut:

1. Pegawai yang memiliki hak kewenangan penuh dalam mengatur dan mengendalikan penggunaan anggaran dari masing-masing unit satuan kerja SKPD di Kota Banda Aceh. SKPD akan dijadikan responden sebanyak 2 orang.

2. Minimal memiliki pengalaman kerja 1 (satu) tahun dalam jabatan yang sedang dipangkunya. Alasannya agar dapat lebih memahami proses kerja dalam jabatan yang sedang dipangkunya.

Tabel 3.1 menunjukkan daftar nama dinas dan badan yang menyusun dan mengajukan RKA-SKPD pemerintah Kota Banda Aceh.

\section{Tabel 3.1}

\section{Data Responden Penelitian}

\begin{tabular}{|c|c|c|}
\hline No. & Nama SKPD & Responden \\
\hline 1 & Sekretariat Daerah & 2 \\
\hline 2 & $\begin{array}{l}\text { Dinas Pengelolaan Keuangan dan } \\
\text { Aset Daerah }\end{array}$ & 2 \\
\hline 3 & $\begin{array}{l}\text { Dinas Kependudukan dan Pencatatan } \\
\text { Sipil }\end{array}$ & 2 \\
\hline 4 & $\begin{array}{l}\text { Badan Kepegawaian, Pendidikan dan } \\
\text { Pelatihan }\end{array}$ & 2 \\
\hline 5 & $\begin{array}{l}\text { Kantor Pelayanan Perizinan Terpadu } \\
\text { Satu Pintu }\end{array}$ & 2 \\
\hline 6 & Dinas Pekerjaan Umum & 2 \\
\hline 7 & Dinas Kesehatan & 2 \\
\hline 8 & $\begin{array}{l}\text { Dinas Pendidikan Pemuda dan } \\
\text { Olahraga }\end{array}$ & 2 \\
\hline 9 & $\begin{array}{l}\text { Badan Perencanaan Pembangunan } \\
\text { Daerah }\end{array}$ & 2 \\
\hline 10 & Sekretariat DPRK & 2 \\
\hline 11 & Dinas Kebudayaan dan Pariwisata & 2 \\
\hline 12 & Badan Pemberdayaan Masyarakat & 2 \\
\hline 13 & $\begin{array}{l}\text { Dinas Perhubungan, Komunikasi dan } \\
\text { Informatika }\end{array}$ & 2 \\
\hline 14 & Dinas Sosial dan Tenaga Kerja & 2 \\
\hline 15 & $\begin{array}{l}\text { Dinas Perindustrian, Perdagangan, } \\
\text { Koperasi dan UKM }\end{array}$ & 2 \\
\hline 16 & $\begin{array}{l}\text { Dinas Kelautan, Perikanan dan } \\
\text { Pertanian }\end{array}$ & 2 \\
\hline 17 & $\begin{array}{l}\text { Dinas Kebersihan dan Keindahan } \\
\text { Kota }\end{array}$ & 2 \\
\hline 18 & Dinas Syariat Islam & 2 \\
\hline 19 & Inspektorat & 2 \\
\hline 20 & $\begin{array}{l}\text { Badan Kesatuan Bangsa, Politik, } \\
\text { Perlindungan Masyarakat dan } \\
\text { Penanggulangan }\end{array}$ & 2 \\
\hline
\end{tabular}




\begin{tabular}{|c|l|c|}
\hline No. & Nama SKPD & Responden \\
\hline 21 & $\begin{array}{l}\text { Rumah Sakit Umum Daerah } \\
\text { Meuraxa }\end{array}$ & 2 \\
\hline 22 & $\begin{array}{l}\text { Kantor Pemberdayaan perempuan } \\
\text { dan Keluarga Berencana }\end{array}$ & 2 \\
\hline 23 & Kantor Perpustakaan dan Arsip & 2 \\
\hline 24 & Kantor Lingkungan Hidup & 2 \\
\hline 25 & $\begin{array}{l}\text { Satuan Polisi Pamong Praja dan } \\
\text { Wilayatul Hisbah }\end{array}$ & 2 \\
\hline 26 & Sekretariat Baitul Mal & 2 \\
\hline 27 & $\begin{array}{l}\text { Sekretariat Majelis Permusyawaratan } \\
\text { Ulama }\end{array}$ & $\begin{array}{l}\text { Sekretatiat Majelis Pendidikan } \\
\text { Daerah }\end{array}$ \\
\hline 28 &
\end{tabular}

\begin{tabular}{|c|l|c|}
\hline No. & Nama SKPD & Responden \\
\hline 29 & Sekretariat Majelis Adat Aceh & 2 \\
\hline \multicolumn{2}{|l|}{ Jumlah Responden } & $\mathbf{5 8}$ \\
\hline
\end{tabular}

Sumber: E-kinerja kota Banda Aceh.

\section{Teknik Pengumpulan Data}

Instrumen penelitian ini adalah merupakan sebagai alat ukur yang dikembangkan dan mengacu pada karakteristik variabel penelitian yang diukur. Secara garis besar penjabaran dari definisi opersional beserta indikator-indikatori nstrumen penelitian dapat dilihat pada Tabel berikut ini :

Tabel 3.2

Operasionalisai variabel

\begin{tabular}{|c|c|c|c|}
\hline No. & Variabel & Indikator & Skala \\
\hline 1 & $\begin{array}{l}\text { Implementasi Pengelolaan } \\
\text { Anggaran Berbasis Kinerja }\end{array}$ & $\begin{array}{ll}\text { - } & \text { Ekonomis } \\
\text { - } & \text { Efisiensi } \\
\text { - } & \text { Efektif } \\
\end{array}$ & Interval \\
\hline 2 & $\begin{array}{l}\text { Kepemimpinan } \\
\text { (X1) }\end{array}$ & $\begin{array}{ll}\text { - } & \text { Fungsi instruksi } \\
\text { - } & \text { Fungsi konsultasi } \\
\text { - } & \text { Fungsi partisipasi } \\
\text { - } & \text { Fungsi delegasi } \\
\end{array}$ & Interval \\
\hline 3 & $\begin{array}{l}\text { Sumber daya Manusia } \\
(\mathrm{X} 2)\end{array}$ & $\begin{array}{l}\text { - Pendidikan dan pelatihan } \\
\text { - Keahlian dan Keterampilan } \\
\text { - Pengalaman Kerja }\end{array}$ & Interval \\
\hline 4 & $\begin{array}{l}\text { Monitoring dan Evaluasi } \\
\text { (X3) }\end{array}$ & $\begin{array}{l}\text { - Sistem monitoring dan evaluasi } \\
\text { - Teknik monitoring dan evaluasi } \\
\text { - Kendala dalam monitoring dan evaluasi } \\
\text { - Tindak lanjut hasil monitoring dan evaluasi }\end{array}$ & Interval \\
\hline 5 & Regulasi (X4) & $\begin{array}{l}\text { - } \text { Respon terhadap regulasi } \\
\text { - Konsistensi pelaksanaan } \\
\text { - Kemudahan pelaksanaan }\end{array}$ & Interval \\
\hline
\end{tabular}

\section{Metode Analisis}

Metode analisis data yang digunakan adalah regresi linear berganda yang bertujuan untuk menguji dan menganalisis, baik secara bersama-sama maupun secara parsial pengaruh faktor kepemimpinan, sumber daya manusia, monitoring dan evaluasi, dan regulasi pada implementasi penganggaran berbasis kinerja di kota Banda Aceh yang akan diolah dengan program Statistical Package for Social Science (SPSS) 22.

Adapun persamaan untuk menguji hipotesis secara keseluruhan pada penelitian ini adalah sebagai berikut:

$$
Y_{1}=\alpha+\beta_{1} X_{1}+\beta_{2} X_{2}+\beta_{3} X_{3}+\beta_{4} X_{4}+e
$$

\section{Keterangan:}

$\mathrm{Y}=$ Implementasi Penganggaran Berbasis Kinerja;

$\alpha \quad=$ Konstanta;
$\mathrm{X}_{1} \quad$ Kepemimpinan;

$\mathrm{X}_{2} \quad$ = Sumber daya manusia;

$\mathrm{X}_{3} \quad=$ Monitoring dan Evaluasi;

$\mathrm{X}_{4} \quad=$ Regulasi;

$\beta_{1}, \beta_{2}, \beta_{3}, \beta_{4} \quad=$ Koefisien Regresi;

$$
\mathrm{e} \quad=\text { error terms. }
$$

\section{Hasil Analisis Dan Pembahasan Statistik Deskriptif}

Dalam penelitian ini peneliti menyebarkan kuesioner pada 58 pejabat dilingkungan Pemerintah Kota Banda Aceh dan telah diterima kembali sebanyak 58 kuesioner (100\%). Lama waktu responden dalam mengembalikan kuesioner berbedabeda, namun rata-rata pengembalian kuesioner berkisar antara seminggu sampai dua minggu. Setelah kuesioner diisi oleh responden, peneliti mengumpulkan kembali kuesioner tersebut untuk 
ditalabusi dan selanjutnya diolah dengan menggunakan program SPSS 22 dan Microsoft Excel 2007.

\section{Uji Validitas dan Reliabilitas}

Pengujian validitas data dalam penelitian ini dilakukan secaara statistik, yaitu dengan menggunakan uji Pearson Product-Poment Coefficient of Correlation dengan bantuan sofware komputer melalui program Statistic Package for Social Science (SPSS) 22.0. Jika angka korelasi yang diperoleh lebih besar dari pada angka kritik ( $r$ hitung $>r$ tabel) maka instrumen tersebut dikatakan valid. Berdasarkan hasil uji validitas dapat disimpulkan bahwa tidak seluruh item pertanyaan untuk mengukur masing-masing variabel penelitian dinyatakan valid. Hal ini dapat dilihatkan bahwa tidak seluruh $r$ hitung lebih besar $r$ tabel. Dimana nilai $r$ tabel untuk sampel sebanyak 58 adalah 0,258 .

Uji reliabilitas digunakan untuk menunjukkan sejauh mana suatu alat pengukuran dapat dipercaya. Untuk menentukan suatu instrumen reliabel atau tidak maka bisa menggunakan batas nilai alpha 0,6. Berdasarkan analisis reliabilitas dapat diketahui bahwa $\alpha$ untuk masing-masing variabel yaitu kepemimpinan sebesar 0,666 , sumber daya manusia sebesar 0,617, monitoring dan evaluasi sebesar 0,805, regulasi sebesar 0,827, dan implementasi penganggaran sebesar 0,634. Dari keseluruhan nilai alpha tersebut, semua nilai besar dari 0,600 dengan demikian seluruh variabel mempunyai instrumeninstrumen yang handal untuk dipakai dalam penelitian.

\section{Uji Asumsi Klasik}

Berdasarkan hasil uji normalitas data dengan menggunakan uji kolmogorov-Sminov dan dengan melihat uji grafik, maka dapat disimpulkan bahwa data mempunyai distribusi normal. Hal ini dapat diketahui dengan melihat nilai kolmogorov-Sminov sebesar 0.85 dengan tingkat signifikansi sebesar 0.20. Jika signifikansi nilai Kolmogorov-Smirnov lebih besar dari 0.05 , maka dapat dinyatakan bahwa data mempunyai distribusi normal. Hal ini juga didukung dengan grafik dimana data mengikuti garis diagonal.

Berdasarkan hasil uji multikolonieritas, dapat dilihat bahwa nilai tolerance dari 4 variabel bebas semuanya lebih besar dari 0,10 . Demikian pula nilai VIF leibih kecil dari 10. Dengan demikian dapat disimpulkan bahwa model regresi tidak mengindikasikan adanya multikolonieritas atau asumsi non multikolonieritas terpenuhi.

Uji asumsi heteroskedastisitas menyimpulkan bahwa model regresi tidak terjadi heteroskedastisitas. Dengan kata lain terjadi kesamaan varian dari residual dari satu pengamatan ke pengamatan yang lain. Kesimpulan ini diperoleh dengan melihat penyebaran titik-titik yang menyebar secara acek, tidak membentuk sebuah pola tertentu yang jelas, serta tersebar baik diatas maupun dibawah angka 0 pada sumbu Y.

Pengaruh Gaya Kepemimpinan, Sumber Daya Manusia, Monitoring dan Evaluasi, dan Regulasi secara bersama-sama terhadap Implementasi Penganggaran Berbasis Kinerja

Berdasarkan hasil pengujian statistik, secara bersama-sama variabel kepemimpinan, sumber daya manusia, monitoring dan evaluasi, dan regulasi berpengaruh terhadap implementasi penganggaran berbasis kinerja pada kota Banda Aceh. Hasil pengujian secara simultan menunjukkan nilai signifikansi $\mathrm{F}>0,05$ yaitu 0,030 yang berarti model regresi fit atau hipotesis diterima.

Penelitian ini mendukung penelitian Sabri (2013) menunjukkan bahwa kepemimpinan, sumber daya pengelola anggaran serta monitoring dan evaluasi berpengaruh signifikan positif terhadap implementasi pengelolaan anggaran berbasis kinerja di Kota Bukittinggi.

Selain itu, penelitian ini mendukung penelitian Azhar (2008) menunjukkan bahwa regulasi dan sumber daya manusia yang secara bersama-sama mempengaruhi tingkat keberhasilan penerapan Permendagri nomor 13 tahun 2006 pada pemerintahan kota Banda Aceh.

\section{Pengaruh Gaya Kepemimpinan terhadap Implementasi Penganggaran Berbasis Kinerja}

Hasil penelirian menunjukkan bahwa kepemimpinan tidak berpengaruh terhadap implementasi penganggaran berbasis kinerja. Hasil pengujian statistik menunjukkan tingkat signifikan kepemimpinan sebesar 0,465 yang lebih besar dari tingkat signifikan 0,05 sehingga hipotesis yang dibuat ditolak. 
Hasil penelitian sejalan dengan pradana (2014) yang menunjukkan bahwa faktor kepemimpinan tidak berpengaruh signifikan terhadap penerapan anggaran berbasis kinerja. Hasil penelitian ini bertentangan dengan teori yang dikemukakan oleh BPKP yang menyatakan bahwa kepemimpinan adalah salah satu faktor yang mempengaruhi penerapan anggaran berbasis kinerja. Hal ini menunjukkan bahwa variabel kepemimpinan kurang memiliki peranan penting dalam implementasi penganggaran berbasis kinerja di Kota Banda Aceh.

\section{Pengaruh Sumber Daya Manusia terhadap Implementasi Penganggaran Berbasis Kinerja}

Hasil penelitian menunjukkan bahwa sumber daya manusia tidak berpengaruh signifikan terhadap implementasi penganggaran berbasis kinerja. Pengujian statistik yang dilakukan menunjukkan bahwa nilai signifikansi 0,179 yang lebih besar dari tingkat signifikan 0,05 sehingga hipotesis yang dibuat ditolak.

Hasil Penelitian ini menolak hasil penelitian Sabri (2013) menunjukkan bahwa sumber daya pengelola berpengaruh signifikan terhadap implementasi pengelolaan anggaran berbasis kinerja di Kota Bukittinggi dan juga menolak hasil penelitian Azhar (2008) yang menunjukkan bahwa sumber daya yang cukup berpengaruh signifikan terhadap keberhasilan penerapan Permendagri 13 Tahun 2006. Hal ini berarti faktor sumber daya manusia tidak selamanya menjadi salah satu faktor penentu keberhasilan dari implementasi anggaran berbasis kinerja dalam lingkup pemerintah kota Banda Aceh. Kemungkinan hal ini disebabkan karena tidak semua anggota organisasi terlibat dalam proses penyusunan anggaran.

\section{Pengaruh Monitoring dan Evaluasi terhadap Implementasi Penganggaran Berbasis Kinerja}

Pada hasil penelitian ini menunjukkan pengaruh monitoring dan evaluasi terhadap implementasi penganggaran berbasis kinerja adalah positif dan tidak signifikan. Positif terlihat dari koefisien regresi monitoring dan evaluasi sebesar 0,197 dan nilai signifikan sebesar 0,242 yang lebih besar dari tingkat signifikan 0,05 sehingga hipotesis yang dibuat di tolak.

Hasil penelitian ini tidak sejalan dengan Sabri (2013) yang menyatakan bahwa monitoring dan evaluasi berpengaruh signifikan terhadap implementasi pengelolaan anggaran berbasis kinerja di Kota Bukittinggi. Hal ini kemungkinan disebabkan belum adanya umpan balik yang diperoleh dari monitoring dan pengevaluasian, sehingga perlu dianalisa kembali secara cermat dengan melihat keterserapan dana dan pencapaian indikator kinerja anggaran serta melibatkan instansi terkait dalam tim monitoring dan evaluasi, dan memberikan sanksi kepada SKPD yang gagal menerapkan anggaran berbasis kinerja

\section{Pengaruh Regulasi terhadap Implementas Penganggaran Berbasis Kinerja}

Pada hasil penelitian ini menunjukkan pengaruh regulasi terhadap implementasi penganggaran berbasis kinerja adalah negatif dan signifikan. Negatif terlihat dari koefisien regresi regulasi sebesar -0,041 dan nilai signifikan sebesar 0,619 yang lebih besar dari tingkat signifikan 0,05 sehingga hipotesis yang dibuat di tolak.

Hasil penelitian ini menunjukkan bahwa hubungan antara regulasi dan implementasi penganggaran berbasis kinerja negatif, yaitu semakin sering perubahan peraturan dilakukan oleh pemerintah maka akan menurunkan tingkat keberhasilan penerapaannya dari peraturan tersebut. Tetapi hasil penelitian ini menunjukkan nilai yang tidak signifikan yang berarti hubungan antara regulasi dan implementasi anggran berbasis kinerja yang negatif tersebut tidak dapar diterima.

Hasil penelitian ini mendukung penelitian Azhar (2008) menunjukkan bahwa hubungan antara regulasi dan keberhasilan penerapan Permendagri 13 tahun 2006 negatif dan tidak signifikan.

\section{Kesimpulan, Keterbatasan Dan Saran}

Berdasarkan hasil analisis dan pembahasan yang telah dilakukan sebelumnya, maka dapat ditarik kesimpulan bahwa faktor gaya kepemimpinan, sumber daya manusia, monitoring dan evaluasi, dan regulasi secara bersama-sama berpengaruh terhadap implementasi penganggaran berbasis kinerja di Kota Banda Aceh. sedangkan pengujian secara parsial menunjukkan bahwa faktor gaya kepemimpinan, sumber daya manusia, monitoring dan evaluasi, dan regulasi tidak berpengaruh terhadap implementasi berbasis kinerja di Kota Banda Aceh. 
Penelitian ini memiliki keterbatasan pada beberapa hal, Penelitian yang digunakan menggunakan kuesioner, ada kemungkinan respon bias dari responden karena tidak serius dalam memberikan jawaban,serta objek penelitian ini hanya dilakukan pada lingkup pemerintah kota Banda Aceh dan belum mencakup kabupaten lain khususnya untuk provinsi Aceh, jadi penelitian ini belum dapat digeneralisir secara luas.

Penelitian selanjutnya diharapkan dapat meneliti untuk cakupan yang lebih luas misalnya SKPD Provinsi. Dan mengembangkan keberhasilan instrumen pengukuran indikator anggaran berbasis kinerja yaitu adanya target kinerja, pengukuran kinerja, standar pelayanan minimal, analisis standat belanja, dan standar harga dan Sebaiknya peneliti selanjutnya menggunakan metode observasi atau pengamatan langsung kepada objek penelitian untuk menghindari respon bias akibat penggunaan kuesioner atau menggunakan metode eksperimen sebagai penganti metode kuesioner.

\section{Daftar Pustaka}

Alfiandri. 2010. Pengaruh Gaya Kepemimpinan dan Motivasi Berprestasi terhadap Kinerja Pegawai Dinas Kebudayaan dan Pariwisata Kota Pekanbaru. Jurnal Ilmu Administrasi Negara. Volume 10 No. 1: 37-47.

Avionita, Venni. 2013. Pengaruh Implementasi Anggaran Berbasis Kinerja terhadap Kinerja Program Peningkatan Disiplin Aparatur Instansi Pemerintah Daerah (Studi Kasus pada Badan Perencanaan Pembangunan Daerah Kota Bandung). Skripsi tidak dipublikasikan. Fakultas Ekonomi Universitas Widyatama. Bandung.

Azhar. 2007. Faktor-Faktor yang Mempengaruhi Keberhasilan Penerapan Permendagri No.13 pada Pemerintah Kota Banda Aceh. Tesis Tidak diterbitkan. Medan. Program Pascasarjana Universitas Sumatera Utara.

Badan Pengawasan Keuangan dan Pembangunan. 2005. Pedoman Penyusunan Anggaran Berbasis Kinerja (Revisi). Jakarta.

Idris, Amiruddin dan Win Konadi. 2012. Pengaruh Regulasi dan Ketersediaan Anggaran terhadap Kinerja Pelayanan Aparatur SKPD dan Implikasinya pada Kualitas Pelayanan Publik di Provinsi Aceh. Jurnal kebangsaan. Volume 1. No.1: 11-21.

Izzaty, Khairina Nur. 2011. Pengaruh Gaya Kepemimpinan dan Kualitas Sumber Daya
Manusia terhadap Penerapan Anggaran Berbasis Kinerja Badan Layanan Umum (Studi pada BLU Universitas Diponegoro Semarang). Skripsi. Program Strata Satu Universitas Diponegoro Semarang.

Kurnia. 2008. Anggaran Berbasis Kinerja: Implementasi pada Penyusunan APBD. Jurnal Akuntansi, Manajemen Bisnis dan Sektor Publik (JAMBSP). Volume 5. No.1: 51-57.

Mardiasmo. 2002. Akuntansi Sektor Publik. Yogyakarta: Penerbit Andi.

Mesfriati, Sari. 2009. Analisis Implementasi Kebijakan Anggaran Berbasis Kinerja di Sekretariat Jenderal Departemen Hukum dan HAM. Skripsi. Jakarta: Fakultas Ilmu Sosial dan Ilmu Politik Universitas Indonesia.

Mufarrohah, Sutrisno T dan Bambang Purnomosidhi. 2013. Pengaruh Budaya Organisasi, Komitmen Organisasi, Gaya Kepemimpinan, dan Kompetensi terhadap Kinerja Pemerintahan Daerah (Studi Empiris pada Kabupaten Bangkalan). Jurnal InFestasi. Volume 9. No. 2: 123-136.

Muktiali, Muhammad. 2009. Penyusunan Instrumen Monitoring dan Evaluasi Manfaat Program Pembangunan di Kota Semarang. Jurnal Riptek. Volume 3. No. 2: 11-20.

Nur, Nunuy Afiah, and Oman Rusmana. 2014. The Impact of Budgeting Approaches on the Budgeting Implementation and Local Governance (Study in Indonesia). Word Journal of Social Sciences. Volume 4. No. 3: $1-11$.

Peraturan Pemerintah Nomor 13 Tahun 2006. Tentang Pedoman Pengelolaan Keungan Daerah.

Peraturan Pemerintah Nomor 59 Tahun 2007. Tentang Perubahan Atas Peraturan Menteri Dalam Negeri Nomor 13 Tahun 2006 tentang PedomanPengelolaan Keungan Daerah.

Peraturan Pemerintah Nomor. 105 tahun 2000. Tentang Pengelolaan dan Pertanggungjawaban Keuangan Daerah.

Peraturan Pemerintah Nomor 20 Tahun 2001. Tentang Pembinaan dan Pengawasan Penyelenggaraan Pemerintahan Daerah.

Sabri. 2013. Analisis Faktor-Faktor yang Mempengaruhi Implementasi Pengelolaan Anggaran Berbasis Kinerja di Kota Bukit Tinggi. . Jurnal Ekonomi STIE Haji Agus Salim Bukittinggi. Volume XIV. No.2: 4659. 
Sekaran, Uma dan Roger Bougie. 2010. Research Methods for Business, $5^{\text {th }}$ Edition. United Kingdom: John Wiley \& Sons Ltd. 